\title{
The Kurdish Crisis and Allied Intervention in the Aftermath of the Second Gulf War
}

\author{
Peter Malanczuk *
}

\section{Introduction}

The defeat of the Iraqi army at the end of February 1991 at the hands of the coalition forces led by the United States was followed by widespread uprisings in Iraq against the Government of President Saddam Hussein. There were two separate major rebellions in the predominantly Shia southem provinces of Iraq and the northem Kurdish provinces. By the end of March the Iraqi armed forces were able to crush the southern rebellion and to recapture a number of towns in the north from the Kurds without allied interference. In late March vast numbers of Kurdish refugees fled from the advancing Iraqi military towards the borders of Turkey and Iran. Their plight and the problems they posed for neighbouring countries increasingly gave rise to international concern.

On 3 April 1991, the UN Security Council adopted Resolution 687 setting out the terms of a full ceasefire in the Gulf which were, albeit reluctantly, accepted by Iraq. On 5 April 1991, the Security Council passed Resolution 688 which condemned 'the repression of the Iraqi civilian population in many parts of Iraq, including most recently in Kurdish populated areas, the consequences of which threaten international peace and security'. ${ }^{\prime}$ On 9 April 1991, the Security Council adopted Resolution 689 in order to create a demilitarized zone between Iraq and Kuwait. The zone was to be monitored by a 1,440 UN Iraq-Kuwait Observer Mission (UNIKOM) for which all five permanent Security Council members were prepared to provide military personnel. On 11 April 1991, the Security Council notified Iraq that a ceasefire in the Gulf was formally in effect. ${ }^{2}$

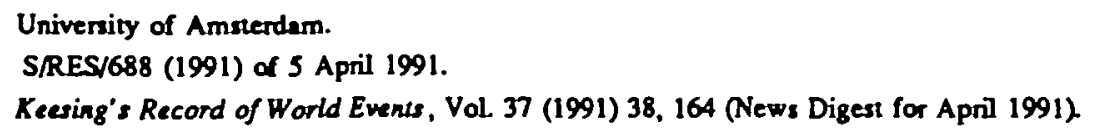


While the Security Council was cocupied with taking these measures, international diplomatic efforts in support of the Kurdish refugees, who were amassed under extremely harsh conditions in the mountains in the border regions with Turkey and Iran, concentrated on emergency relief operations and on finding solutions for an adequate protection for the Kurds in Iraq itself. The idea of establishing Kurdish 'safe havens' in northern Iraq under allied military protoction was advanced. It only materialized, however, when the United States changed its position not to intervene in Iraq and finally decided to commit troops, together with the United Kingdom, France, and other states, to Kurdistan for humanitarian reasons; in spite of strong objections raised by Iraq.

The following examines the legality under international law of the allied intervention in Iraq during the Kurdish Crisis in 1991. In order to put the legal issues into proper perspective, it is first necessary to try to establish the relevant factual background in as much detail as possible, bearing in mind the scarcity and inconsistency of literature and press reports.

\section{Factual Background}

The Kurdish population, which is estimated to amount to between 8 and 30 million people, ${ }^{3}$ does not have an independent state but lives as a minority mainly in Turkey, Iraq, Iran, Syria and in smaller groups in the USSR and Lebanon.4 According to recent estimates the Kurds represent between 19 and $24 \%$ of the population of Turkey, 23 to $27 \%$ of Iraq, 10 to 16\% of Iran and 8 to $9 \%$ of Syria. ${ }^{5}$ The difficulty in establishing their precise number is due to official denial of their existence - in Turkey, they have been referred to as 'mountain turks' - and to the unreliability of statistics supplied by both governments and Kurdish nationalists.

Tracing their origin back to the Medes who conquered Nineveh in $612 \mathrm{BC}$, the Kurds assert that they are a distinct nation which has never really acquired political

Meyers Grosses Taschenlexiton, Vol 12 (2nd. ed. 1987) 282 states that almont half of the Kurtish people live in the eartem part of Turkey, about a quarer in Inn, some $20 \%$ in Irag and the ahen in Syris and the USSR

4 For en ensalysis of the Kurdish problem see M. Short, A. MaDermod, The Kurds Minority Rights Group Repon No. 23, 1975), G. Chaliand (ed), People Withous a Coustry (1980), S.C Pelletiere, The Kurdr: An Unseable Element in the Gulf (1984); D. MeDowall. The Kurds (Minority Rights Group Repon No. 23, rev. ed. 1985); H. Hunnum, Aulonomy, Sovercignty, and Self-Determination. The Accommodation of Conflicting Rights (1986), Chapter 9 'The Kurds'. at 178-202; Slugett. 'The Kurds', in Cardri (ed.), Saddan's Iraq - Revolution or Reaction? (1989); Hippler, 'Kurtistan - ein ungelostes Problern im Mituleren Oxten', 38 Vereinie Nationen (1990) 202-205.

5 Hannum, supra note 4, at 179, with references. Bredshaw, 'After the Gulf War. the Kurds'. The World Today. May 1991, at 78, rates that the Kurds, as the fourth larges national group in the Middle Ears after Arabs, Perrians and Turks, amount to $20-25$ million in toul, with 9-10 mil lion in Turkey, 5 million in Iran, and 4 million in Irap Hippler, supra note 4, at 202, woggests that the toxal number of Kurds today exceeds 15 milion. 
independence. ${ }^{6}$ It is more likely that the ancestors of the Kurds came from several sources; some from Turkic, Armenian, or Assyrian tribes, but most probably from Indo-European groups. ${ }^{7}$ While the Kurds have a north-western Iranian linguistic origin in common, they are separated by two major dialects with considerable local variation and a number of sub-dialects, which seems to make communication between the various tribes and regions difficult, though possible. Tribal structures have traditionally dominated Kurdish society and continue to do so to a remarkable extent. A clear national identity began to emerge in a class of urban Kurdish intellectuals in the second half of the 19th century, but tribalism as well as regional and feudal loyalities stood in the way of its development on a broad scale. Thus, in practice, the Kurds never achieved unity in their struggle for independence against foreign domination, but remained always at least as much involved in fighting each other as combatting Turkish, Iraqi or Iranian troops. ${ }^{8}$

For many centuries Kurdistan had remained a buffer region between Turkey and Persia subject to the control of one or other of these empires. By 1639 three quarters of the Kurds had come under Ottoman rule and in the 19th century there were repeated uprisings particularly against Turkey. Following the defeat of the Outoman Empire in World War I, the 1920 Treaty of Sevres provided not only for the creation of the three Arab states of Hejaz (later Saudi-Arabia), Syria and Iraq, but also for an Armenian state and a Kurdish state. In 1921 Iraq became a monarchy under the rule of Feisal, who had been deprived of Syria by the imposition of a French mandate. The Treaty of Sevres, however, was superseded by the 1923 Treaty of Lausanne. The latter confirmed the plan to create the three Arab states, but no longer mentioned either Armenia or Kurdistan. It was Anglo-French collusion and rivalry in redrawing the map of the Middle East, as well as British interest in controlling oil rich areas, that led to the rejection of an independent Kurdistan and the artificial extension of Iraq to include a predominantly Kurdish north.

Thus, the seeds were laid for continuous Kurdish revolts in Iraq which intensified after southern Kurdistan - the Ottoman province or vilayet of Mosul - was awarded by the League of Nations in 1925 to the new Arab state of Iraq, and therefore in reality placed under British mandate, with some guarantees for the appointment of Kurdish officials and the use of the Kurdish language. Such pledges, however, were not included in the Anglo-Iraqi treaty which terminated the British mandate in 1930. After the 1958 coup d' etat against the monarchy, relations between the Kurds and the new military government initially appeared promising on the basis of the new constitution which referred to a partnership between Arabs and Kurds in Iraq. ${ }^{9}$

6

See Shon, MeDermot, supre note 4, at 6, also claiming that the 'most famous Kurd of all times was Saledin, who fought Richard the Liontean and the Crusaders and regained Jerusalem for Islem in 1187'.

7 Hennum, supro note 4, at 178.

8 See Hippler, supre note 4, at 202-203.

9 The following is based upon the instruaive summery given by Hippler, supro note 4, at 203 204. 
However, the Kassem Government had developed close relations with Kurdish tribes who were enemies of the famous Kurdish tribal leader Mullah Mustafa Barzani. Therefore, civil strife broke out between various Kurdish groups, later followed by a Kurdish uprising against the Bdath Government. In 1970 the Bath Government and the Kurds concluded a peace agreement which reaftirmed Kurdish rights and envisaged the creation of an autonomous region of Kurdistan. However, the $1974 \mathrm{Law}$ of Autonomy in the Area of Kurdistan announced by the Iraqi Government was refuted by the Kurds as falling short of the peace agreement. Fighting continued with thousands of Kurds fleeing to Turkey and Iran.

In the First Gulf War the Kurdish Democratic Party (KDP) under the leadership of Barzani's sons cooperated with Iran against Baghdad and infiltrated Iraqi territory partly side by side with Iranian Pasdaran, while Iraq was supporting the Iranian Kurds against Teheran in the Iranian part of Kurdistan. ${ }^{10}$ On the other hand, the patriotic Union of Kurdistan (PUK), which had been founded under the leadership of Jalal Talabani in the mid seventies in opposition to Barzani's KDP, offered the Iraqi Government help against Iran and the KDP. It is reported that in the mid eighties 150,000 Kurds or more were fighting with Baghdad against Iran and the KDP, which had to pay dearly at the end of the war for its collaboration with Teheran. In 1988 the Iraqi Army crushed the alliance of Iranian and Kurdish KDP forces ruthlessly by using all kinds of arms available, including chemical weapons. About 5,000 civilians were killed by poison gas in March 1988 in the village of Halabja. ${ }^{11}$

During the Second Gulf War, President Bush invited several times the people of Iraq to rise against the regime, 12 although this was denied by the State Department spokeswoman, Margaret Tutwiler. ${ }^{13}$ Probably, this was intended to invite a military coup against President Saddam Hussein. At any rate, in view of American interests in the region as a whole, it did not mean support for a division of Iraq in the wake of the Shiite insurrection in the south and a corresponding Kurdish uprising in the north. On the contrary, the territorial integrity of defeated Iraq needed to be secured in order to preserve Iraq's function as a balance, primarily against Iran. Although the Islamic Republic did not say so officially, it was clear that only Iran had an interest in a successful Shiite revolution in the south of Iraq. The establishment of an independent Kurdistan in the north of Iraq, on the other hand, not only would have raised the issue of control over the important oil resources in the area, but also

10 Hippler, supra note 4, at 204.

11 Hippler, supra nowe 4, a 204.

12 Mayall, 'Non-Intervention, Self-Determination and the New World Order', 67 Intermational Affairs (1991) 421, 428 reproduces the following remarks made by Presideni George Bush to the American Academy for the Advancement of Science on 15 February 1991 from the Financial Times, 16-17 February 1991: 'But there's another way for the bloodshed to stop, and that is for the Iragi miliury and the Inaqi peopte to take mutuen into their own hand to force Seddem Hussein the dietulor to step aride and to comply with the UN and then rejoin the family of peace-loving nations'.

13 Keasing's Record of World Events. Vol 37 (1991) 38, 127. 
would have posed a threat to the security of neighbouring States, in particular Turkey.

There is reason to assume that this scenario and the unwillingness of the United States to commit its military to a presence of unknown duration in a country engaged in a civil war were key factors for the political decision not to go through with the campaign against Saddam Hussein at the end of February 1991. ${ }^{14}$ The official reason given for the suspension on 27 February 1991 of 'Operation Desert Storm' was that the goal to push Iraq out of Kuwait had been achieved. ${ }^{15}$ Later it became clear that this decision allowed a large number of tanks of the Iraqi Republican Guard to escape to the north before General Schwarzkopf was able to complete his encirclement of the mass of Iraqi tanks assembled in the area west of Basra ${ }^{16}$ As a result, the Republican Guard, which had deployed almost half of its forces in the north of Iraq, remained able to function after the war. Thus, it appears that the domestic survival of the regime in power was preferred as a lesser evil, at least for the time being, to the carving up of the state of Iraq.

When in mid-March of 1991 the Kurds, following the lead taken by the Shiite rebellion in the south of Iraq, also rose in the north they were able to operate on the basis of an alliance called the Kurdish Front which had been principally formed by the two major Kurdish organizations, Jalal Talabani's Patriotic Union and Masud Barzani's Kurdish Democratic Party. ${ }^{17}$ The Kurdish pershmerga fighters, joined by defectors from the pro-government Kurdish militia (jash), made quick advances in the north of Iraq and gained control over the Kurdish cities Sulaymaniyah, Arbil, Dohuk and the oil centre of Kirkuk. However, they were unable to resist counter-attack by the Republican Guard, supported by combat helicopters and, according to Kurdish sources, combat aircraft. Well remembering the Iraqi use of chemical weapons in 1988 the population of the cities fled in panic mainly towards Iran and Turkey. It was alleged by the Kurdish leader Barzani that about 3 million Kurds had fled into the mountains as part of a 'tactical withdrawal' to escape the govemment's programme of 'genocide and torture against our people'. ${ }^{18}$

There was an urgent appeal from Kurdish leaders to France, Saudi Arabia, the United Kingdom and the United States to seck immediate intervention by the United Nations. ${ }^{19}$ However, by early April 1991 there was no coordinated international response. France made an effort, but failed to persuade the UN Security Council on 2

For a similar view see Ruehl, 'Der Krieg an Golf. Militirischer Verlauf und politisch-strategische Probleme', Europa-Archiv (8/1991) 237, 246.

18 Keesing's Recond of World Events, Vol. 37 (1991) 38, 126 (News Digest for April 1991). This cource also quotes the Iranien Foreign Minister, Ali Akbar Vellayat, as having arted on 3 April 1991 that 'more then two million Kurds are lenving under constant bombardment'. 
April 1991 to adopt a resolution to provide protection for the Kurds. There was opposition from China, the USSR and the United States who shared the view that this would create a precedent for the involvement of the Security Council in internal matters. ${ }^{20}$ Various reasons for the refusal were put forward by the US administration, such as the unlikely success of insurgents in view of their lack of a central command, the absence of a mandate from the United Nations extending the objective of the operation beyond the liberation of Kuwait, and the President's reluctance to put the lives of American soldiers at risk by becoming involved in a civil war which had been continuing for decades. 21

This atritude prevailed for some time, but eventually altered in view of the position taken by other states and public pressure resulting from reports in the media. At the beginning of April, Turkey, ${ }^{22}$ France $^{23}$ and Iran ${ }^{24}$ sent letters in support of the Kurds to the United Nations Security Council. Due to French persistence, the discussion finally resulted in the adoption on 5 April of Resolution 688 . While the resolution was rejected by Iraq, ${ }^{25}$ it reflected growing international condemnation of Iraq's treatment of the Kurdish people. ${ }^{26}$

Furthermore, the idea was advanced of creating UN 'safe havens' backed by military forces in northern Iraq to protect the Kurds from further attacks by the Iraqi Government. In one form or another this idea was quickly endorsed, inter alia, by Austria, Turkey, and European leaders attending the summit meeting of the European Communities on 8 April 1991 in Luxembourg. ${ }^{27}$ The decision in Luxembourg was based upon a British proposal which envisaged 'enclaves' for Kurdish refugees on Iraqi territory close to the borders with Turkey and Iran under the supervision and detailed management of the United Nations. ${ }^{28}$

On 8 April 1991, a White House spokesman stated that the United States had 'no position' on the question of Kurdish 'safe havens' and a State Department

Keesing's Record of World Events, Vol. 37 (1991) 38, 127 (News Digest for April 1991).

Hotinger, supre note 16, at 440.

Leaer of 2 April 1991, $\$ / 22435$.

Leter of 4 April 1991, S/22442.

Letters of 3 and 4 April 1991, S/22436 and S/22447.

Kecsing's Record of World Events, Vol. 37 (1991) 38, 127 (News Digest for April 1991) mentions that the permentent representative of Iraq wo the UN lodged with the Secresary-General a formal procest againat the resolution.

Keasing's Record of World Events. Vol. 37 (1991) 38, 127 (News Digest for April 1991) mentions the following: On 5 April 1991 NATO, eccusing the Government of Inq of 'massive human rights violations', demanded that 'every pressure ... be brought to bear to bring Iragi au thorities to nop the repression without delry'. Germeny's Foreign Minister, Hens-Dietrich Genscher, described Ing's actions as 'genocide' on 5 April 1991 and, on 13 April 1991, suggerted a trial of Prerident Saddern Hussein for 'crimes aguins humanity'. According to reports, the Prime Minister of Australia, Bob Hawke, also called for international ection in favour of the Kands.

Keesing's Record of World Events. Vol. 37 (1991) 38, 127 (Newn Digen for April 1991).

Frantfurter Allgemeine Zeiturg 10 April 1991 at $1-2$ 
spokesman was unable to give the proposal 'specific endorsement'. ${ }^{29}$ Nevertheless, on 11 April 1991, the President of the United States denied reports that there was a rift between the United States and its European allies over the issue of Kurdish 'enclaves'. ${ }^{30}$ In fact, on 10 April 1991, the United States took a significant step to protect the Kurds by requiring Iraq to cease all military activity north of the 36th parallel. This included a part of Kurdish territory from the Turkish border up to a line south of Mosul but excluded the oil area of Kirkuk. The United States also wamed Iraq that it would use force if there was any military interference in intermational relief efforts for the Kurds. ${ }^{31}$

While the Government of Iraq dismissed the 'safe haven' plan and threatened to prevent its implementation by all available means, ${ }^{32}$ the Kurdish leader Barzani welcomed it as 'a big humanitarian and political step forward' and called upon all states 'to back it and implement it as soon as possible'. ${ }^{33}$ Iran, on the other hand, made it clear that it was unlikely to accept Kurdish 'safe havens' near its border. ${ }^{34}$ Iran also criticized the intemational relief effort, in particular the United Nations, for channelling aid through Turkey without considering Iran's needs.

On 17 April 1991, armed forces of the United States and other countries began to move into northem Iraq with the declared aim of setting up camps to secure the safety of Kurdish refugees and of coordinating relief supplies. As stated by the President of the United States, the intention was 'to turn over the administration of, and security for these sites as soon as possible to the UN.'35

Iraq denounced the allied action but it did not respond militarily. It continued to negotiate with both the United Nations Mission led by Eric Suy, Personal Representative of the UN Secretary-General, as well as with the United Nations Inter-Agency Mission led by Sadruddin Aga Khan, Executive Delegate of the UN Secretary-General for the United Nations Humanitarian Programme for Iraq, Kuwait and the Iraq/iran and Iraq/Turkey Border Areas. ${ }^{36}$ On 18 April 1991, the Government of Iraq and Sadruddin Aga Khan, for the United Nations, signed a Memorandum of Understanding concerning the role of the United Nations in providing humanitarian assistance in Iraq. ${ }^{37}$

Keesing's Record of World Events, Vol. 37 (1991) 38, 127 (News Digest for April 1991).

Ibid.

Ibid.

Frantfurter Allgemeine Zeitwng 10 April 1991 all.

Keesing's Record of World Events, Vol. 37 (1991) 38, 127 (News Digest for April 1991).

Ibid. a 38, 128, citing a statement by Velleyati on 21 April 1991.

Ibid., at 38, 127.

Appointed on 9 April 1991 by the UN Secretary-General in response to Resolution 688.

Letier dated 21 April 1991 from the Permanent Representative of Irag to the United Nations addressed to the Secretary-General, UN Doc. S/22513, 22 April 1991, which contuins, as an

'Annex', a Lener deted 21 April 1991 from the Minister of Foreign Affairs of Iraq addressed to 
Under the name 'Operation Provide Comfort' the allied intervention force established a small triangle zone at the border in the north of Iraq between Zahko, Amadiya and Dohuk, but excluding the city of Dohuk. ${ }^{38}$ This was declared to be a security zone under the protection of the allied troops and non-accessible to Iragi forces. The Kurdish refugees were brought from the mountain slopes into this area where they were supplied with food and tents. Many returned to their own quarters in neighbouring cities. The occupation of almost 10,000 square $\mathrm{km}$ of Iraqi territory (extending some $100 \mathrm{~km}$ along the Iraqi-Turkish border and some $60 \mathrm{~km}$ south ${ }^{39}$ ) by more than 13,000 soldiers from various countries, including the United States, Britain, France, the Netherlands, Spain, Italy and Australia, lasted about 3 months. ${ }^{40}$ The operation guaranteed 450,000 Kurdish refugees a safe return home. The last Turkish border camp (at Cukura) was closed on 3 June 1991.41 According to US official figures, about 13,000 Kurds who had sought refuge in the mountains on the Iraqi-Turkish border had died before reaching allied 'safe havens'.

At the same time as the creation of the security zone, UN observers were dispatched in the whole of Iraq in critical areas, including the Kurdish cities outside of the security zone. ${ }^{43}$ But beyond humanitarian care, the role of the United Nations in the northem enclave remained undefined for some time. ${ }^{44}$ In May 1991, negotiations between the United Nations and Iraq continued on the deployment of a small police force (of about 500 ) in the north of Iraq to replace the allied troops. ${ }^{45}$ While the United States and the other allies were in favour of transferring their responsibility in the north of Iraq to such a UN contingent, Iraq at first resisted the proposal. In mid May there were positive signs that a preliminary agreement would be reached with Iraq, the main issues apparently concerning the size of the force and the question whether it should be armed. ${ }^{46}$

The Kurdish city of Dohuk, a provincial capital with about 380,000 inhabitants prior to the exodus of the Kurds, became a test of the effectiveness of the security provided to the returning refugees by the allied presence. It was not included in the

\footnotetext{
the Secretary-General, and as an 'Encloture', the 18 April 1991 Memorandum of Understanding.

38 Hottinger, supra note 16, it 442.

39 The Economist 11 May 1991 at 55 a seq.

40 Frantfwrter Allgemeine Zeivwng 16 July 1991 at 6 . It seems that originally more than 17,000 troops from France. Germany, Italy, the Netherlands, the United Kingdom and the United Sules were expected to paricipate, see Keesing's Record of World Events, Vol. 37 (1991) 38, 127 (News Digen for April 1991).

41 Keesing's Record of World Events, Vol. 37 (1991) 38, 308 (News Digest for April 1991).

42 bid. Anocher repon mentioned states that op to 6,700 Inaqi refuzees, mortly children under five, had died during a two-month period in Tustish campa along the border.

43 Houinger, supra note 16, at 442

44 The Economist 11 May 1991 at 56.

45 Frankfurer Algemeine Zeitung 16 May 1991 \& 7.

46 Frantfurter Allgemeine Zeitwng 16 May 1991 at 7.
} 
Peter Malenczalk

security zone and the allies used their stand-off from the city as a bargaining chip in persuading Iraq to accept the substitution of the allied troops in the security zone by a UN contingent. On 22 May 1991, an agreement was reached. 47 It provided for the withdrawal of Iraqi military from the city and its environment and for its deployment $10 \mathrm{~km}$ to the south. Furthermore, Iraq consented to withdraw its special police. Finally, the agreement permitted members of the allied forces to enter Dohuk to help restore public facilities. The commander of the US forces in the north later explained that the accord did not signify the extension of the allies' security zone. ${ }^{48}$ When Iraq finally agreed to admit a maximum of 500 'United Nations Guards', the UN immediately sent 10 officers from Geneva to Dohuk on 19 May 1991.49

At that time, the Kurdish part of Iraq was divided threefold. The security zone in the north-west was occupied and controlled by about 11,000 allied soldiers. Kurdish forces held a broad strip along the border to the cast and the south, including several towns (Halabja, Qala Diza, Ranja, Rawandiz) and, surrounded Iraqi garrisons in other places. The remainder was under the control of the Iraqi army. ${ }^{50}$

On 29 May 1991, a US military spokesman announced that the allies would begin withdrawing their troops from northem Iraq on 15 June 1991.51 However, US troops suspended their planned withdrawal from northerm Iraq on 21 June 1991 in view of the decision by the Westem allies to deploy a rapid reaction force (RRF) based in the south of Turkey to ensure further protection of Kurdish refugees. ${ }^{52}$ The last 3,000 soldiers of the allied forces in the security zone withdrew in mid July $1991 .{ }^{53}$ With the consent of Turkey, however, an intervention force ('Operation

Frantfurter Allgemeine Zeiturg 23 May 1991 at 1.

Keesing's Record of Warld Events, Vol. 37 (1991) 38, 211 (News Digest for May 1991).

The Economirt 25 May 1991 at 60. Keesing's Record of World Events, Vol. 37 (1991) 38, 211 (News Digest for May 1991), reports thas moves to create a UN force in the norh were rejected by the Government of Iraq on 9 May 1991. It further notes that the Ingi Govermment agreed on 20 May to allow a UN observer team to enter Dohuk. The relevant agreement be tween Ing and the United Nations whe negotiated on 17 and 18 May 1991 and ideatified as an 'Anmex' to the 18 April 1991 Memorendum of Underunding. This annex is reproduced in 30 IIM (1991) 862. It rutes that as 'a first atep, ten United Nations Guards have been dispatched to Dohuk, on 19 May 1991, in order to estublish a United Nations presence at the sub-office and depots of the town' (para. 2). The annex later notes that the 'number of Guards in the Contingent will be kept under review as further units are dispatched locher assignments than in Dahut are mentioned in the preceding park 3., PM], bur will not exceed a woll strength of $500^{\circ}$ (par. 4.).

The Economirt 8 June 1991 at 64.

Keesing's Record of World Events, Vod. 37 (1991) 38, 211 (News Digea for May 1991).

Kecsing's Record of World Events, Vol. 37 (1991) 38, 308 (News Digent for June 1991). noces that US Secreury of Sunte James Baker had indicated on 7 June, after talks with UK Foreign Secrelary Douglas Hurd in Copenhagen, that the USA would consider postponing troop withdrawals until 'the security of the Kurdish population is assured'. On 25 June, UK Prime Mininer John Major nated that the UK forces would remain in northern Iraq until the Kurtish population received assurmecs guannteeing their sufety.

Frankfurter Allgemeine Zeitung $16 \mathrm{July} 1991$ at 6. 
Raised Hammer' ${ }^{54}$ ) of about 5,000 soldiers from the United States, Britain, France, Italy, the Netherlands and Turkey, ${ }^{55}$ remained positioned in the south of Turkey (Silopi and two other cities) to intervene in Iraq if necessary. ${ }^{56}$ These troops left on 10 October, but some American, British and French aircraft remained at the Turkish base of Incirlik.

\section{The Legality of the Allied Intervention}

From a purely moral and humanitarian point of view there seems to be little difficulty in welcoming the allied military intervention in Iraq to protect the Kurdish refugees. The assessment of the legality of the operation under international law, however, raises more complex issues. This is due to the prohibition of the use of force in Article 2, paragraph 4, of the United Nations Charter which, at least according to the prevailing view, has also become part of general unwritten international law. 57 It is also relevant in this connection that the prohibition of the use of force overlaps with the principle of non-intervention in matters which are recognized by international law as being solely within the domestic jurisdiction of states. ${ }^{58}$ Thus, the Friendly Relations Declaration of 1970, in explaining the 'principle conceming the duty not to intervene in matters within the domestic jurisdiction of any State, in accordance with the Charter', clearly states that:

No State or group of States has the right to intervene, directly or indirectly, for any reason whatever, in the internal or external affairs of my other State. Consequently, armed intervention and all other forms of interference or attempted threats against the Hemmer'. NRC Handelsblad 12 September 1991 at 12.

55 Frankfurter Allgemeine Zeiturg 23 September 1991 at 5, mentioning a figure of 4,600 allied soldiers under American leadership.

Hottinger, supre noce 16, at 442 , alleges that this force was not only placed there to intervene in case the Ingi Government once more resored to the massive use of force against its own civilians, bur alwo in case cease-fire conditions were noc met. However, there is no indication that this particular assernbly of forces was designed to do more then protect the Kurds.

See G. Arangio-Ruiz, Third Report on State Responsibility. Intemational Law Commission, Forty-third session, UN Doc ANCN.4/440/Add.1, 19 July 1991, 8 et seq. with references and : discussion of minority views atvocating that there are still forms of unilatenl (individual or collective) reton to force which may be invoked under the concepts of amed reprisals or self defence. See also Malmezut, "Countermeasures and Self-defence as Circumstances Precluding Wrongfulness in the International Law Commission's Dreft Articles on State Responsibiliny'. in M. Spinedi, B. Simms, United Nations Codification of State Responsibility (1987) 197, 212 et seq.

For details see Oppermann, 'Intervention', in R. Bernhardt (ed.), Encyelopedia of Public International Law, Insubment 3 (1982) 233 a req.; Schroder, 'Non-Intervention, Principle of. in R. Bemharch (ed), Encyclopedia of Public International Law. Instalment 7 (1984) 358 a seg. 
personality of the State or against its political, economic and cultural elements, are in violation of international law.59

Had Iraq given its consent to the occupation of part of its territory by the allied forces for the purpose of helping the Kurdish refugees, there would have been no legal problem. But that was not the case. On the contrary, as noted in the letter dated 21 April 1991 to the UN Secretary-General transmitting the text of the Memorandum of Understanding of 18 April between Iraq and the United Nations, Iraq requested the United Nations, in accordance with the agreement, to assume responsibility for the relief centres established by United States and other foreign forces in northern Iraq and noted that the allied measure would 'constitute a serious, unjustifiable and unfounded attack on the sovereignty and territorial integrity of Iraq'. The letter further states that:

It should be pointed out that the Government of Iraq, while opposing the steps taken by Unitod states forces and the foreign forces cooperating with them ... hes not hindered these operations because it is not opposed to the provision of humanitarian assistance to Iraqi citizens who are in need of it and because it wishes to avoid any complication that may prevent the return of all Iraqi citizens in security to their places of residence. 60

Leaving aside the question of whether the Government of Iraq after its military disaster was actually in any position to resist the allied action, in view of the lack of consent by Iraq to any violation of its sovereignty, the allied armed intervention requires some other legal justification.

One consideration may be whether the intervention in Iraq could be based upon support for the self-determination of the Kurds. The principle of self-determination of people in contemporary international law is still to a large extent unclear in its precise scope and content. It is safe to say, however, disregarding the special practice relating to cases of decolonization, that it does not provide for the general recognition of the right of groups to secede from the states in which they reside. ${ }^{61}$ Self-determination can be implemented by a sufficient degree of autonomy within the existing state structure. Indeed the Kurds in Iraq have primarily aimed for this objective, realizing that it is unlikely that they will gain independent statehood due to the interests of neighbouring states. Thus, immediately after the Republican Guard had recaptured the Kurdish cities, Kurdish leaders decided to enter into negotiations with

Declaration on Principles of Intemational Law Conceming Friendly Relations and Co-openation Amons Stutes in Acoordance with the Charter of the United Nations. UN General Assembly Resolution 2625 (XXV), 24 October 1970, UN Doc A/8028.

60 Letter dated 21 April 1991 from the Permenen Repreaentutive of Inq to the United Nations addreased to the Secretary-General, UN Doc. S/22513, 22 April 1991. which contuins, as an 'Annex', a Letter deted 21 April 1991 from the Minister of Forcign Affairs of Inag addressed to the Secretary-General, and as an 'Enclosure', the 18 April 1991 Memorandum of Undersunding. The quocation is from the letter in the Annex, p. 2

61 See Tharer, 'Self-determination', in R. Bemhardt (ed.), Encyclopedia of Public International Lew, Instatment 8 (1985) 470, 474. 
Baghdad to enable the Kurdish population to return and to prevent settlements by Arabs in Kurdish areas. 62 On 24 April 1991, Talabani announced that President Saddam Hussein had agreed 'in principle' to grant a measure of autonomy to the Kurds on the basis of the 1970 autonomy agreement. This was confirmed by the Iraqi Govemment, ${ }^{63}$ but there were difficulties as regards the implementation of the agreement. 64 After four months of negotiations, in August 1991 both sides agreed on a draft text which was submitted for approval to the various Kurdish opposition groups. 65 However, following the new outbreak of hostilities between the Kurds and the Iraqi army in October 1991, other sources indicate that the talks on Kurdish autonomy had made no further progress because of the failure of Saddam Hussein to keep his promise to install a democratic government in Baghdad. ${ }^{66}$ There were later reports from Western relief organizations that the Government of Iraq prevented the supply of petrol and food in order to exert pressure upon the Kurds to accept the Govemment's autonomy scheme. ${ }^{67}$

There are two main reasons - one legal and one factual - why the principle of self-determination, as applied to the cause of the Kurds, does not justify the allied armed intervention. As to the first, whatever the exact meaning of the right of selfdetermination, it does not justify third-party intervention in suppon of secessionist movements. In view of the central legal principles upon which the present international system is based, including territorial integrity, sovereignty and political independence of states, it has been correctly observed that

[a] general right to military interventions in aid of insurgents would also hardly be compatible with the primary purpose of the United Nations to maintaining international peace and security to which, pursuant to Article 1 of the Charter, the principle of self-determination is subordinuted. 68

62

63

64 Imporsant points at issue included the size and borden of the autonomous area, the regime to govern the oil centre Kirkuk, foreign relations of the Kurds with regard to the Wea, and the question of ams, Frantfurter Allgemeine Zeitung 2 July 1991 at 6 . According w Keesing's Record of World Events. Vol. 37 (1991) 38, 308, the conditions which emerged before the round of ulks on 16 June 1991 were 'that Kurdish leaders suspend links with the West and side with the ruling Bdath party against Shie insorgents and ocher "arificial" organizations, in re turn for joint Iragi-Kurdish administration of the oil city of Kirkuk and exclusive Kurdich con. trot over Dohuk, Sulaimanya and Arbil'.

65 Frantfuruer Allgemeine Zeiturg 23 August 1991 a 1 . There is no specific information on the contents, except that the text would provide for far-reaching political rights and autonony of the Kurds and for arrangements conceming the retum of the refugees. It is further mentioned that it would not provide for complete Kurdish control over the oil centre Kirkuk.

66

67

Frantfurer Algemeine Zeitung 4 November 1991 at 6.

Thurer, supre nock 61, a 474. In view of the uncertinties relating to the right of self-determi nation, Thirer considers it premature to accept secession as 'an integnal element' of that right. However, he suggests that the tuditional law of intervention has undergone modification in 
As to the second, there is no indication that the purpose of the allied intervention in Iraq was more than purely humanitarian nor did it aim to lend support to a form of self-determination of the Kurds. This is clear both from statements made by officials and from the temporary and limited scope of the military engagement.

The question, therefore, arises whether the allied action can be justified as a case of 'humanitarian intervention'. As distinct from military rescue operations to protect a state's own nationals abroad - which was not at issue in 'Operation Provide Comfort' - the concept of humanitarian intervention, in its 'classical' sense, refers to unilateral intervention by armed force to protect the inhabitants of another state from inhuman treatment ${ }^{69}$ There is no need to enter into the old controversy on whether such a right of humanitarian intervention existed in customary intemational law before 1945 and whether it survived the comprehensive prohibition of the use of force by Article 2, paragraph 4, of the United Nations Charter. ${ }^{70}$ It may suffice here to note that authors who support a right of humanitarian intervention consider the use of force to be legal in cases of gross violation of human rights if all peaceful means to protect the victims have been unsuccessful, if the United Nations has failed to help, and if the use of armed force is proportional to the goals of the rescue mission. ${ }^{71}$ An analysis of state practice shows that recent cases of humanitarian intervention are rare, and that humanitarian issues have never been the only reasons invoked for military intervention. ${ }^{72}$ The prevailing view rejects the legality of humanitarian intervention in contemporary intermational law mainly because of the danger of abuse by more powerful states, which could use it as an excuse to justify an exception to the prohibition of the use of force. ${ }^{73}$ In view of the danger of legal uncertainty, even authors such as Frowein who have advanced the concept of obligations erga omnes, have been unwilling to admit the possibility that third states may legally launch forcible reprisals in response to violations of human rights. ${ }^{74}$ However, the following observation by Shaw remains illuminating:

Nevertheless, it is not inconceivable that in some situations the international community might refrain from adopting a condemnatory stand where large numbers of lives have been saved in circumstances of gross oppression by a state of its citizens

thas military assistance to sovernments manifealy suppressing a claim to self-determination is no longer lawful

69 See Beyerlin, 'Humanitarian Intervention', in R. Bernhardt (ad.), Encyclopedia of Pubtic International Low. Instalment 3 (1982) 211 et seq with further references.

70 In addition to Beyerlin, ibid, and the literature listed in his bibliognaphy, see N. Ronzitui, Rescuing Nationals Abroad Through Military Coercion and Intervention and Grounds of Humaning (1985), as well as the references in Fischer, in K. Ipsen, Volkerrecht (3rd ed. 1990) 872 ef seq.

71 See Verwey, 'Hummitarian Intervention', in A. Cassese (od.) Current Legal Regulation of the Use of Force (1980) 57, 74 ex seq.

72 See LA. Sicilimos, Les réactions dicentralises d $r$ illicice (1990) 475 et seq.o at 485.

73 Fischer, in K. Ipsen, supre note 70, at 885.

74 See Malanczalk, 'Countermearares', supra note 57, at 230 et seq with references. 
due to an outside intervention. This does not of course mean that it constitutes a legitimate principle of international law. 75

Thus, under international law armed intervention on humanitarian grounds in favour of (foreign) inhabitants ${ }^{76}$ of other states is legal only if the UN Security Council determines that gross violations of human rights committed by a state against its population, or a part of it, constitute a breach of the peace (or threat to the peace) within the meaning of Article 39 of the UN Charter and decides upon enforcement measures. 7 This leads to the analysis of Security Council Resolution 688 condemning the repression of the Kurds.

The relevant draft resolution 78 was put on the agenda of the Security Council on 5 April 1991 by Belgium and France, joined by the United Kingdom and the United States as sponsors. ${ }^{79}$ The meeting had been convened in response to requests by Turkey and France. The Council also took note of letters from Iran, Iraq and Luxembourg. At their request, Canada, Denmark, Germany, Greece, Iran, Iraq, Ireland, Italy, Luxembourg, Norway, the Netherlands, Pakistan, Portugal, Spain, Sweden and Turkey were invited to participate in the discussion of the Council without the right to vote. 80

This draft resolution was adopted as Resolution 688 by 10 voles in favour (Austria, Belgium, Cote d'Ivoire, Ecuador, France, Romania, USSR, United Kingdom, United States, Zaire), 3 against (Cuba, Yemen, Zimbabwe) and 2, including one permanent member, abstaining (China and India). The significance that was attached to the issue is apparent from the fact that 31 states expressed their views on the matter either before or after adoption of the resolution.

The text of Resolution $688^{81}$ commences with a reference to duties and responsibilities of the Security Council for the maintenance of international peace and security, but then immediately recalls Article 2, paragraph 7, of the Charter. ${ }^{82}$ It continues to express grave concem over 'the repression of the Iraqi civilian population

M.N. Shaw, International Law (3rd ed. 1991) 725. For a similar consideration in the different context of a state liberating its own nationals from extreme danger see Beyerlin. 'Humanitarian Intervention', spra note 69, at 214.

This wording intends to set aside the different set of problems relating to the amned interven. tion in other states in procection of own nationals in serious denger. A. Verdross, B. Simma, Universelles Volkerrechs (3rd ed. 1984) 291. S/22448.

UN Security Council, Provisional Vetatim Record, S/PV 2982, 5 April 1991, 3.

Ibid., 2, 21 (Norway and Portugal), and 91 (Caneda and Greece).

Text reproduced in $30 \mathrm{ILM}$ (1991) 858-859.

It provides that: 'Noching contained in the present Charrer shall authorize the United Nations $\omega$ intervene in matten which are essentially within the domestic jurisdiction of any sute or shall require the Members to submit such matuen to seulement under the present Charter, but this principle shall not prejudice the application of enforcement measures under Chapter VII.' For in interesting view on the relation of Article 2, pangraph 7, to general intemational law, see I. Brownlie, Principles of Public International Law (4h ed. 1990) 294 a seq. 
in many parts of Iraq, including most recently in Kurdish populated areas which led to a massive flow of refugees towards and across international frontiers and to cross border incursions, which threaten international peace and security in the region'. While the preamble records that the Security Council was deeply disturbed "by the magnitude of the human suffering involved', it also reaffirmed 'the commitment of all Member States to the sovereignty, territorial integrity and political independence of Iraq and of all States in the area'.

The operative part of Resolution 688 condemned in unequivocal terms 'the repression of the Iraqi civilian population in many parts of Iraq, including most recently in Kurdish populated areas, the consequences of which threaten international peace and security in the region' (paragraph 1). It demanded that Iraq, 'as a contribution to removing the threat to intemational peace and security in the region', end the repression immediately and expressed the hope for 'an open dialogue' to ensure 'that the human and political rights of all Iraqi citizens are respected' (paragraph 2). After requiring Iraq to allow immediate access by international humanitarian organizations (paragraph 3), the resolution requested the Secretary-General to pursue his humanitarian efforts in Iraq and 'to report forthwith, if appropriate on the basis of a further mission to the region, on the plight of the Iraqi civilian population (paragraph 4) and to 'use all the resources at his disposal, including those of the relevant United Nations agencies, to address urgently the critical needs of the refugees and displaced Iraqi population' (paragraph 5). The resolution concluded by appealing to all Member States and to all humanitarian organizations to contribute to the relief efforts (paragraph 6), demanding that Iraq cooperate with the Secretary-General (paragraph 7), and deciding 'to remain seized of the matter' (paragraph 8).

It has been noted that Resolution 688 has no real precedent in United Nations practice, although there is some link to UN measures in the area of disaster relief operations. ${ }^{83}$ While this resolution, in contrast to others adopted against Iraq, makes no explicit reference to Chapter VII of the Charter in general or to Article 39 in particular, it has been interpreted as evidence that the Security Council may adopt measures under Chapter VII with regard to an internal situation if a massive violation of human rights amounts to a threat 10 or breach of the peace, in spite of Article 2, paragraph 7, of the Charter. ${ }^{84}$ A closer analysis of the statements made in the Security Council at the occasion of the adoption of the resolution, however, reveals that even those states which were supporting the resolution carefully balanced the role of the Security Council in this matter with the principle of non-interference in the internal affairs of Iraq. ${ }^{85}$ There is also no indication in that discussion that the resolution "was understood to provide further ground for continuing economic

Heinz, Philipp, Wolfrum, 'Zweiker Golfkrieg: Anwendungsfall von Kapilel VI der UN-Chars:, 39 Vereinle Nationen (1991) 121 a seq., a 125.

84

Ibid.

85 See UN Doc. S/PV.2982, 5 April 1991 (Provisional). 
The Kurdish Crisis and Allied Intervention

sanctions', 86 while it is clear that no renewed military action was mentioned in the resolution or even contemplated in the Security Council. Therefore, the precedent value of this resolution with regard to a more active role of the Security Council under Chapter VII in cases of gross violation of human rights threatening international peace should not be overestimated, although it will certainly serve as an important reference in the future for other cases. In practice, apart from the tasks assigned to the Secretary-General in that particular case, Resolution 688 amounted to little more than a formal censure of Iraq. Otherwise it is most likely that it would have been vetoed by China. ${ }^{87}$

At any rate, Resolution 688 did not endorse the military protective measures taken by the allied forces in creating the security zone in the north of Iraq. In fact, as Oscar Schachter correctly observes:

the Security Council was not asked to authorize or endorse the protective measures in the safery zones, presumably because not all of the permanent members were prepared to support thern. The absence of explicit Security Council endorsement, together with the basic Charter provision against intervention in matters essentially within domestic jurisdiction, was cited by dissenting UN members as grounds for condernning the use of troops in the safety zones as Charter violations of serious import. All states, it was argued, had reason to fer the effect of that precedent. 88

This corresponds with the rather reserved reaction of the UN Secretary-General to the 'safe havens' proposal. He immediately raised the question whether enclaves for the Kurds could be imposed upon Iraq in disrespect of its sovereignty. ${ }^{89}$ On 17 April 1991, he further expressed the view that any plan to deploy foreign troops in northem Iraq would require permission by Iraq. He also noted that a UN supported police force would need the consent of the Security Council.90 While there was no express authorization of the deployment in May 1991 of the United Nations Guards in Iraq by the Secretary-General, this action may be deemed as covered by paragraph 5 of

Schechter, 'United Nations Law in the Gulf Conflict', 85 AIL (1991) 452 et req., at 468.

The reluesence of China to scepp the resolution becume sparent from the following statement of is representutive in the Security Council:

'Mr. LI Danoyu (Chins) (interpretation from Chinese): We are concerned with the situation in Ing and the huge influx of refugees into Turkey and Inn, as described in the letters from the Permanent Representalives of those two countries, and we wish wo express sympathy for the difficulties confronting Tutkey and Iran as a resuh of thas influx. However, this is a question of greal complexity, because the intemal affairs of a country are also involved. According to pargraph 7 of Article 2 of the Charter, the Security Council should not consider or take action on questions conceming the intemal affairs of any Sute. As for the international aspects in volved in the question, we are of the view that they should be settled through the appropriate channels. We support the Secretury-General in rendering humanitarian assistance to the refugees through the relevant orgenizations. Based on the position I have jun set our, we abstained in the voce on the resolution', UN Doc. S.PV.2982, 5 April 1991 (Provisional) 55-56. Schactuer, supre noce 86, at 469.

89 Frankfwer Allgemeine Zeitung 10 April 1991 at 1 . See also Keesing's Record of World Events, Vol 37 (1991) 38, 128 (News Digen for April 1991) as to reservations by others. 
Resolution 688, requesting the Secretary-General to 'use all the resources at his disposal ... to address urgently the critical needs of the refugees and displaced Iraqi population..$^{91}$ However, it is wrong to assume that this deployment occurred without express Iraqi agreement. ${ }^{92}$ Based on discussions held on 17 and 18 May 1991, an annex to the Memorandum of Understanding concluded between the United Nations and Iraq on 18 April 1991 laid out the details of the deployment of the United Nations Guards Contingent. It even dealt with the sensitive issue of arming the guards in the following manner:

United Nations Guards will be authorized to carry side-arms (pistols/revolvers), which will be provided by the Iraqi authorities (aubject to the approval of the United Nations with respect to make. model, calibre and munitions). While it is not anticipated that all Guards will be so armed. United Nations guidelines and practices will be followed in this regard. 93

Thus, in requesting individual member states to contribute to the UN deployment, the United Nations made it clear that only non-military staff could be considered due to Iraq's view that a military presence was not acceptable. ${ }^{94}$ In June 1991, the UN Secretary-General emphasized that the 500 UN delegates designated to operate in the north of Iraq were not a police force, but served, as 'human witnesses', to induce the refugees to return and convince them that they will be secure even after the withdrawal of the allied troops from the north of Iraq.95

This underlines that the deployment of the UN guards in Iraq and the method of providing them with small arms in the end required the consent of Iraq. Resolution 688 alone was not a sufficient basis for such a UN operation. This makes it difficult to invoke the United Nations' involvement in the Kurdish crisis as an argument in support of the legality of the allied military intervention to protect the refugees.

91 92 Schechter, supre note 86, at 469, atutes that Irag's socepunce of the UN relief operations did dispatching the contingent of UN guards 'was not expressly authorized by the Security Council or by Ingi agreement'. The latter is incorrect.

93

301LM (1991) 862. (amex, par. 6).

As was the case when the Necheriands was anked, NRC Handelsblad 29 May 1991 at 3.

Frantfurter Allgemeine Zeitung 14 June 1991 a 7. The Kurds were no convinced that they would be afforded adequate protection by 500 lightly amed UN guards, including security men from Genevs offices, the presence of hundreds of intemutional aid workers, plus the continued threat of sanctions (The Economist 8 June 1991 at 63 at seg.) The Kurdish leader Talabani was even quoued as anting to the UN Secretary-General that he "was indifferent when the Kurdish people faced tragedy, and is more concemed with Iragi sovereignty than with genocide and mass deportation', The Economist, ibid., at 64. 
The Kurdish Crisis and Allied Intervention

\section{Conclusion}

There is no doubt that the allied military protoctive action in Iraq was noble and echically sound in reducing massive human suffering, whatever its political motives and irrespective of the question as to why such action has been lacking in many other similar circumstances. However, the above analysis, which falls within the traditional framework of contemporary international law, shows that it is difficult to find a legal basis justifying the allied armed intervention in the Kurdish crisis. Schachter has made an attempt to build a legal case in support of the action by arguing, inter alia, that the Security Council had determined that there was a threat to intemational peace and security, that 'the intemal strife was in some respects a consequence of the international military action, placing responsibility of a political and humanitarian character on the coalition to prevent massive attacks by Iraqi forces against non-combatants belonging to particular ethnic and religious communities'. and that the allied action was limited 'to the necessary protective action for a relatively short period to allow for relief and the eventual retum of the refugees' without seeking to impose 'an internal regime of autonomy or minority rights'.96 While these are certainly highly relevant considerations, they do not overcome the obstacles posed by basic rules of international law to the unilateral (individual or collective) use of force outside the realms of self-defence within the meaning of Aricle 51 of the UN Charter. They would also beg the question of how to evaluate the corresponding responsibility of the coalition towards the plight of the Shiites who had rebelled in the south of Iraq. 97

A discussion is required to determine if the traditional framework of international law needs a thorough reconsideration to allow the United Nations to have an effective role when gross violations of human rights arise and threaten international peace and security. In view of of the USSR's well-known persistent emphasis of the principle of non-intervention into domestic affairs of states, it is interesting to note that then Soviet Foreign Minister, Pankin proposed recently that the United Nations should amend the concept of sovereignty so that in future the international community could intervene in domestic conflicts. ${ }^{98}$ Perhaps the experience of the

96 Schuchter, supra note 86, at 469.

97 Although there were new reports on the prosecution of Iraqi Shiites, on 8 May 1991, the United Sutes withdrew its remeining troops from southern Ireg, Keesing's Record of World Events, Vol. 37 (1991) 38, 211 (News Digen for May 1991). Two deys later, the head of the United Nation's Humanilarian Programme for Irag and Kuwait, Prince Sadruddin Agha Khan, complained that the West had ceased to pay altention to the continuing plight of Shis refugees. On 23 May 1991, the UN Secretary-General's special representuive declared in Baghdad that the UN armed gards would patrol the south in a 'reassurance role'. On 11 June 1991. Iran appesled to the United Nations to procect between 500,000 and 900,000 Shiites allegedly trapped by Iraqi forces in the marahes of southern Irag.

Frantfurter Allgemeine Zeitung 26 September 1991 at 2 . It may be noted with interest in this connection that the former Foreign Minister of the USSR, Schevardnerdec, a few months earlier soggested that the United Nutions should play a role in solving regional conflicts in the Sovia Union, although this nised complicated issues in the USSR. It would not necessarily 
Kurdish crisis may eventually give rise to the emergence of a new rule in customary international law, provided it can find general acceptance as a precedent outside of the peculiar circumstances of the Second Gulf War. It is more likely that the majority of states, especially the less powerful ones, will resent such a development. The Kurdish crisis may also lead to a more active role for the Security Council in incidents of this nature, as has been cautiously suggested by Schachter.

It is unlikely that most governments would approve a brosd right of the United Nations to introduce troops for humeniturien purposes against the wishes of the govemment. However, one camnot exclude the possibility that the United Nations would invoke chapter VII, and its mandatory authority under Articles 42 and 48, in casses of human necessity when the territorial government is unwilling or unable to provide relief and protection. (...) In a case of this kind, the Council is almost certain to premise its decision on a finding that the situation constirutes a threat to international peace and security in view of its transborder implications. 99

The current conflict in Yugoslavia may offer a first test case for such Security Council action. However, the legal significance of the allied intervention to protect the Kurds for the development of intemational law will become apparent only in a long-term perspective. A more immediate practical issue meriting further discussion is how to strengthen the role of Secretary-General in dealing with the humanitarian aspects of such cases on the basis of the experience with the Kurdish crisis.

mean violating sovercignty, if the UN had a say in the setulement of damestic confliats threatening the security of a region, Frankfiorter Allgemeine Zeitwe 17 May 1991 at 2. 